\title{
Myosin heavy chain and cardiac troponin $T$ damage is associated with impaired myofibrillar ATPase activity contributing to sarcomeric dysfunction in $\mathrm{Ca}^{2+}$-paradox rat hearts
}

\author{
Árpád Kovács ${ }^{1} \cdot$ Judit Kalász $^{1} \cdot$ Enikô T. Pásztor $^{1} \cdot$ Attila Tóth $^{1,2} \cdot$ Zoltán Papp $^{1,2}$. \\ Naranjan S. Dhalla ${ }^{3} \cdot J_{\text {Jdit Barta }}^{3,4}$
}

Received: 15 October 2016 / Accepted: 20 January 2017 / Published online: 17 February 2017

(C) The Author(s) 2017. This article is published with open access at Springerlink.com

\begin{abstract}
This study aimed to explore the potential contribution of myofibrils to contractile dysfunction in $\mathrm{Ca}^{2+}$-paradox hearts. Isolated rat hearts were perfused with Krebs-Henseleit solution (Control), followed by $\mathrm{Ca}^{2+}$-depletion, and then $\mathrm{Ca}^{2+}$-repletion after $\mathrm{Ca}^{2+}$-depletion $\left(\mathrm{Ca}^{2+}\right.$-paradox) by Langendorff method. During heart perfusion left ventricular developed pressure (LVDP), end-diastolic pressure (LVEDP), rate of pressure development $(+\mathrm{dP} / \mathrm{dt})$, and pressure decay $(-\mathrm{dP} / \mathrm{dt})$ were registered. Control LVDP $(127.4 \pm 6.1 \mathrm{mmHg})$ was reduced during $\mathrm{Ca}^{2+}$-depletion $(9.8 \pm 1.3 \mathrm{mmHg})$ and $\mathrm{Ca}^{2+}$-paradox $(12.9 \pm 1.3 \mathrm{mmHg})$ with similar decline in $+\mathrm{dP} / \mathrm{dt}$ and $-\mathrm{dP} / \mathrm{dt}$. LVEDP was increased in both $\mathrm{Ca}^{2+}$-depletion and $\mathrm{Ca}^{2+}$-paradox. Compared to Control, myofibrillar $\mathrm{Ca}^{2+}$-stimulated ATPase activity was decreased in the $\mathrm{Ca}^{2+}$-depletion group $\left(12.08 \pm 0.57\right.$ vs. $8.13 \pm 0.19 \mu$ mol $\mathrm{P}_{\mathrm{i}} /$ $\mathrm{mg}$ protein/h), besides unvarying $\mathrm{Mg}^{2+}$ ATPase activity, while upon $\mathrm{Ca}^{2+}$-paradox myofibrillar $\mathrm{Ca}^{2+}$-stimulated
\end{abstract}

Judit Barta

bartajud@gmail.com

1 Division of Clinical Physiology, Institute of Cardiology, Faculty of Medicine, University of Debrecen, Debrecen 4032, Hungary

2 Research Centre for Molecular Medicine, Faculty of Medicine, University of Debrecen, Debrecen 4032, Hungary

3 Department of Physiology and Pathophysiology, Faculty of Health Sciences, St. Boniface Hospital Albrechtsen Research Centre, Institute of Cardiovascular Sciences, College of Medicine, University of Manitoba, 351 Tache Avenue, Winnipeg, MB R2H 2A6, Canada

4 Department of Cardiology, Institute of Cardiology, Faculty of Medicine, University of Debrecen, 22 Móricz Zs krt., Debrecen 4032, Hungary
ATPase activity was decreased $(12.08 \pm 0.57 \quad$ vs. $8.40 \pm 0.22 \mu \mathrm{mol} \mathrm{P}_{\mathrm{i}} / \mathrm{mg}$ protein $\left./ \mathrm{h}\right)$, but $\mathrm{Mg}^{2+}$ ATPase activity was increased $\left(3.20 \pm 0.25\right.$ vs. $7.21 \pm 0.36 \mu \mathrm{mol} \mathrm{P}_{\mathrm{i}} / \mathrm{mg}$ protein/h). In force measurements of isolated cardiomyocytes at saturating $\left[\mathrm{Ca}^{2+}\right], \mathrm{Ca}^{2+}$-depleted cells had lower rate constant of force redevelopment $\left(k_{\mathrm{tr}, \max }, 3.85 \pm 0.21\right)$ and unchanged active tension, while those in $\mathrm{Ca}^{2+}$-paradox produced lower active tension $\left(12.12 \pm 3.19 \mathrm{kN} / \mathrm{m}^{2}\right)$ and $k_{\mathrm{tr} \text { max }}(3.21 \pm 23)$ than cells of Control group $(25.07 \pm 3.51$ and $4.61 \pm 22 \mathrm{kN} / \mathrm{m}^{2}$, respectively). In biochemical assays, $\alpha$-myosin heavy chain and cardiac troponin $\mathrm{T}$ presented progressive degradation during $\mathrm{Ca}^{2+}$-depletion and $\mathrm{Ca}^{2+}$-paradox. Our results suggest that contractile impairment in $\mathrm{Ca}^{2+}$-paradox partially resides in deranged sarcomeric function and compromised myofibrillar ATPase activity as a result of myofilament protein degradation, such as $\alpha$-myosin heavy chain and cardiac troponin T. Impaired relaxation seen in $\mathrm{Ca}^{2+}$-paradoxical hearts is apparently not related to titin, rather explained by the altered myofibrillar ATPase activity.

Keywords Calcium paradox $\cdot$ Myofibrillar ATPase activity $\cdot$ Isolated cardiomyocytes $\cdot$ Myofilament protein degradation

\section{Introduction}

Paradoxically, when a physiologically perfused isolated heart is perfused for a short period of time with a $\mathrm{Ca}^{2+}$ free, otherwise normal Krebs-Henseleit buffer, and then with buffer ensuring again physiological $\left[\mathrm{Ca}^{2+}\right]$, the heart rapidly deteriorates. This memorable, but unexpected observation was first reported by Zimmerman and Hülsmann five decades ago [1]. Thereafter, this adverse effect 
of $\mathrm{Ca}^{2+}$-repletion on a once $\mathrm{Ca}^{2+}$-depleted heart has been known as $\mathrm{Ca}^{2+}$-paradox [2]. Although in vivo pathophysiology does not present exclusive depletion and repletion of $\mathrm{Ca}^{2+}$ during ischemia and reperfusion (I/R), extreme rise of cytosolic $\left[\mathrm{Ca}^{2+}\right]$ is a key element of $\mathrm{I} / \mathrm{R}$ injury [3]. For that very reason, an isolated heart undergoing $\mathrm{Ca}^{2+}$-paradox has been considered to serve a widely accepted model for investigating the mechanisms of structural and functional myocardial injury due to intracellular $\mathrm{Ca}^{2+}$-overload as part of I/R injury [4]. The pathomechanism of $\mathrm{Ca}^{2+}$-paradox has been partly explored. The consequence of $\mathrm{Ca}^{2+}$-repletion after $\mathrm{Ca}^{2+}$-depletion on global left ventricular function is a marked decrease in systolic pressure paralleled by a significant increase in end-diastolic pressure $[5,6]$. The rationale of dramatic contractile impairment due to $\mathrm{Ca}^{2+}$-paradox is myocardial hypercontracture associated with intense ultrastructural damage [7]. Accordingly, $\mathrm{Ca}^{2+}$-depletion initiates a moderate disruption of the adjacent cardiac cells at the intercalated discs [8], $\beta$-dystroglycan is dissipated, and cell-to-cell and cell-extracellular matrix connections break up [9]. Finally, in massive $\mathrm{Ca}^{2+}$-overload hypercontracture develops [10], while the heart becomes pale because of myoglobin loss [11]. Since cell-to-cell detachment is a necessary step in this phenomenon, isolated cardiomyocytes are thought to avert $\mathrm{Ca}^{2+}$-paradox $[12,13]$. These observations altogether suggest that contracture is the main cause of contractile dysfunction in $\mathrm{Ca}^{2+}$-paradox. In contrast, numerous concomitant intracellular changes have been also described in $\mathrm{Ca}^{2+}$-paradox-affected isolated hearts. $\mathrm{Ca}^{2+}$-repletion results in excessive $\mathrm{Ca}^{2+}$ entry with reverse mode of $\mathrm{Na}^{+} / \mathrm{Ca}^{2+}$ exchanger and transient receptor potential channels [14], as well as through non-specific transmembrane influx [9], sarcolemmal disruption [15] with insufficient sarcolemmal $\mathrm{Ca}^{2+}$-activated and $\mathrm{Mg}^{2+}$ ATPase unable to extrude $\mathrm{Ca}^{2+}$ [16], injured microsomal fraction attended with depressed $\mathrm{Ca}^{2+}$-activated and $\mathrm{Mg}^{2+}$ ATPase activity, and $\mathrm{Ca}^{2+}$ binding of the sarcoplasmic reticulum [17], collectively provoking intracellular $\mathrm{Ca}^{2+}$-overload, therefore leading to extensive perturbations of intracellular $\mathrm{Ca}^{2+}$ handling. However, it has not been elucidated yet whether sarcomere disruption and myofilament damage also contribute to the contractile failure in $\mathrm{Ca}^{2+}$-paradox. In rat models of $\mathrm{Ca}^{2+}$-paradox, myosin light chain-1 release [18] and troponin I release together with $\alpha$-fodrin degradation [19] have been reported. Despite $\mathrm{Ca}^{2+}$-paradox has not been a hot topic lately, recent scientific efforts apparently still have been able to provide new insights into the mechanism of $\mathrm{Ca}^{2+}$-overload-induced changes.

In this study, we re-considered the myocardial contractile dysfunction due to $\mathrm{Ca}^{2+}$-paradox, and aimed to explore new mechanisms underlying the decreased global contractility at myofibrillar and cellular level. For this reason, beyond standard procedure of Langendorff method, we tested $\mathrm{Ca}^{2+}$-stimulated and $\mathrm{Mg}^{2+}$ ATPase activity of ventricular myofibrils as well as contractile performance of single ventricular cardiomyocytes, as yet unexamined in rat hearts exposed to $\mathrm{Ca}^{2+}$-paradox. Finally, we tested whether or not molecular targets such as myofilament proteins are injured.

\section{Materials and methods}

Experimental protocols were approved by the University of Manitoba Animal Care Committee and follow the guidelines of the Canadian Council on Animal Care and the guidelines of the National Institute of Health.

\section{Experimental model of $\mathrm{Ca}^{2+}$-paradox}

According to previous protocol practice [5-7], male Sprague-Dawley rat $(250-300 \mathrm{~g})$ hearts were isolated under ketamine and xylazine anesthesia, and were perfused with Krebs-Henseleit solution (in mM: $120.0 \mathrm{NaCl}$, $4.8 \mathrm{KCl}, 1.2 \mathrm{KH}_{2} \mathrm{PO}_{4}, 1.25 \mathrm{CaCl}_{2}, 1.25 \mathrm{MgSO}_{4}, 25.0$ $\mathrm{NaHCO}_{3}$, and 8.6 glucose; $\mathrm{pH}$ 7.4) by using Langendorff method $\left(37^{\circ} \mathrm{C}, 95 \% \mathrm{O}_{2}, 5 \% \mathrm{CO}_{2}\right)$. Hearts were electrically stimulated (300 beats/min) using a Phipps and Bird stimulator (Richmond, VA, USA). Water-filled latex balloon was placed into the left ventricular cavity, and connected to a transducer (model 1050, from BP-Biopac System, Inc., Goleta, CA, USA). Left ventricular developed pressure (LVDP), end-diastolic pressure (LVEDP), rate of pressure development $(+\mathrm{dP} / \mathrm{dt})$ and pressure decay $(-\mathrm{dP} /$ dt) were registered. Initial LVEDP was set to $10 \mathrm{mmHg}$ by inflation of the balloon. Following a 20-min stabilization, hearts were randomized into three groups $(n=7-9 /$ groups) and exposed either to normal Krebs-Henseleit medium containing $1.25 \mathrm{mM} \mathrm{Ca}^{2+}$ for $15 \mathrm{~min}$ (Control), or to $\mathrm{Ca}^{2+}$-depletion for $5 \mathrm{~min}\left(\mathrm{Ca}^{2+}\right.$ free $)$, or to $\mathrm{Ca}^{2+}$-repletion with normal Krebs-Henseleit solution for $10 \mathrm{~min}$ after 5 min of $\mathrm{Ca}^{2+}$-depletion $\left(\mathrm{Ca}^{2+}\right.$-paradox $)$. At the end of the perfusion protocols, hearts were snap frozen in liquid nitrogen and stored at $-70^{\circ} \mathrm{C}$ for further use.

\section{Myofibrillar ATPase activity measurements}

LV myofibrils were isolated ( $n=7-9 /$ groups) as previously described [20] and were suspended in a suspension medium (in mM: $100.0 \mathrm{KCl}, 20.0$ Tris_HCl; pH 7.0). Based on earlier protocol [21], total ATPase activity was measured in the following buffer (in $\mathrm{mM}$ ): 20.0 imidazole, $3.0 \mathrm{MgCl}_{2}, 2.0 \mathrm{Na}_{2} \mathrm{ATP}, 5.0 \mathrm{NaN}_{3}, 50.0 \mathrm{KCl}, 0.01$ free $\mathrm{Ca}^{2+} ; \mathrm{pH}$ 7.0. $\mathrm{Mg}^{2+}$ ATPase activity was determined in the same buffer, except that free $\mathrm{Ca}^{2+}$ was replaced by $1.0 \mathrm{mM}$ EGTA. Reactions were run for $5 \mathrm{~min}$ at $37^{\circ} \mathrm{C}$, and then 
terminated by adding ice-cold $12 \%$ trichloroacetic acid. Following centrifugation, phosphate was determined in the supernatant by colorimetric method [22]. $\mathrm{Ca}^{2+}$-stimulated ATPase activity was calculated from the total and basal $\mathrm{Mg}^{2+}$ ATPase activity.

\section{Contractile force measurements of isolated cardiomyocytes}

Contractile function of skinned ventricular cardiomyocytes ( $n=12-13$ /groups) from isolated hearts perfused by Langendorff method was measured as described previously [23]. Briefly, deep-frozen $\left(-70^{\circ} \mathrm{C}\right)$ tissue samples were mechanically disrupted and membrane-permeabilized by $0.5 \%$ Triton $\mathrm{X}-100$ detergent in isolating solution (in $\mathrm{mM}: 1.0 \mathrm{MgCl}_{2}, 100.0 \mathrm{KCl}, 2.0$ EGTA, $4.0 \mathrm{ATP}, 10.0 \mathrm{imi}-$ dazole; $\mathrm{pH} 7.0$ ) at $4{ }^{\circ} \mathrm{C}$. Each subjected cell was attached at each end to a stainless steel insect needle connecting to either a high-speed length controller (Aurora Scientific, Inc., Aurora, Canada) or a sensitive force transducer (SensoNor AS, Horten, Norway) at $15^{\circ} \mathrm{C}$. Subsequent cardiomyocyte isometric force generation was recorded at sarcomere length of $2.3 \mu \mathrm{m}$ and analyzed by LabVIEW software (National Instruments, Corp., Austin, TX, USA). $\mathrm{Ca}^{2+}$-dependent force production of a single cardiomyocyte was induced by transferring the preparation from relaxing (in mM: $10.0 \mathrm{BES}, 37.11 \mathrm{KCl}, 6.41 \mathrm{MgCl}_{2}, 7.0$ EGTA, 6.94 ATP, 15.0 creatine-phosphate; $\mathrm{pH}$ 7.2) to activating solution (same composition as relaxing solution aside from containing CaEGTA instead of EGTA). In our experiments, $\mathrm{Ca}^{2+}$ concentrations were indicated as $-\log _{10}\left[\mathrm{Ca}^{2+}\right]$ units, and accordingly the $\mathrm{pCa}$ of relaxing solution was 9.0, whereas the $\mathrm{pCa}$ of maximal activating solution was 4.75 . Protease inhibitors were added to all solutions freshly: phenylmethylsulfonyl fluoride (PMSF): $0.5 \mathrm{mM}$; leupeptin: $40 \mu \mathrm{M}$; and E-64: $10 \mu \mathrm{M}$. All chemicals were purchased from Sigma-Aldrich, Corp. (St. Louis, MO, USA).

Maximal and submaximal $\mathrm{Ca}^{2+}$-activated force generation of isolated cardiomyocytes was registered using maximal activating solution and submaximal activating solutions with different $\mathrm{Ca}^{2+}$ concentrations ( $\mathrm{pCa}$ 5.4-7.0), respectively. During $\mathrm{Ca}^{2+}$-contractions, a so-called release-restretch maneuver, i.e., slack test, was applied in order to estimate the rate constant of force redevelopment $\left(k_{\mathrm{tr}}\right)$. Actin-myosin turnover constant $k_{\mathrm{tr}}$ was determined at $\mathrm{pCa}$ values ranging from 4.75 to 6.0. Note that force redevelopment could not be fitted accurately at $\mathrm{pCa}>6.0$ due to the low signal-to-noise ratio. Plots indicating active force values at each $\mathrm{pCa}$ normalized to the corresponding maximum at $\mathrm{pCa} 4.75$ as 1.0 were fitted by a specific sigmoidal function in Origin 6.0 analysis program (OriginLab, Corp., Northampton, MA, USA). It follows that the $\mathrm{pCa}$ value for the half-maximal contraction indicated by
$\mathrm{pCa}_{50}$ defines per se the $\mathrm{Ca}^{2+}$-sensitivity of the contractile machinery. The steepness of the $\mathrm{Ca}^{2+}$-sensitivity curve, reflecting the myofilament cooperation, was calculated by a modified Hill equation and expressed as a coefficient $\left(n_{\text {Hill }}\right)$. $\mathrm{Ca}^{2+}$-independent passive force of the examined cardiac cell was measured by the shortening to $80 \%$ of initial preparation length in relaxing solution. Original forces (in $\mu \mathrm{N}$ ) recorded by this experimental composition were adapted by cross section area-in $\mu \mathrm{m}^{2}$ calculating from the width and height—of each individual cell indicating cardiomyocyte tension (expressed in $\mathrm{kN} / \mathrm{m}^{2}$ ).

\section{Biochemical analysis of myofilament proteins}

LV myocardial tissue samples were pulverized in a chilled mortar and homogenized in an ice-cold buffer containing (in $\mathrm{mM}$ ) $30.0 \mathrm{KCl}, 15.0$ imidazole, $5.0 \mathrm{NaCl}, 1.0 \mathrm{MgCl}_{2}$, 1.0 EGTA, 1.0 EDTA, 0.5 DTT and $\mathrm{CaCl}_{2}, 0.3$ Calpain Inhibitor I (Calbiochem, San Diego, CA, USA), leupeptin, and Phosphatase Inhibitor Cocktail 1 (all from SigmaAldrich except stated otherwise), $\mathrm{pH}$ 7.5. Protein concentration was determined according to the Lowry method. Homogenates were aliquoted and immediately boiled in SDS sample buffer for $3 \mathrm{~min}$. To ascertain protein degradation in the crude homogenates, one-dimensional SDSpolyacrylamide gel electrophoresis (SDS-PAGE) was performed (Bio-Rad Laboratories, Inc., Hercules, CA, USA) in a non-stacking gradient gel system (concentration range: $6-18 \% ; 30 \mu \mathrm{g}$ protein/lane) followed by silver staining [24].

For further analysis of the samples, titin was separated by SDS-PAGE on $2 \%$ agarose-strengthened gels as detailed elsewhere [25]. Protein bands with apparent molecular mass of 3000-3300 kDa were visualized using Coomassie brilliant blue (Reanal, Ltd., Budapest, Hungary). Suspected small myofilament proteins were separated on single-concentration SDS-polyacrylamide gels ( $\alpha$-actinin: 7\%; desmin: 10\%; actin, cardiac troponin $\mathrm{T}$ $(\mathrm{cTnT})$, tropomyosin $(\mathrm{Tm})$, and cardiac troponin I (cTnI): 15\%; myosin light chain-1 and -2 (MLC-1 and MLC-2, respectively): 20\%; Mini Protean II, Bio-Rad; 5-10 $\mu \mathrm{g}$ protein/lane), transferred appropriately and identified by Western immunoblot (Bio-Rad). Enhanced chemiluminescent (ECL) detection was used for protein visualization as previously used [26]. Membranes were probed with the following primary antibodies: anti- $\alpha$-actinin clone EA-53 (Sigma-Aldrich), dilution 1:5000; anti-desmin clone DE-U10 (Sigma-Aldrich), dilution 1:7000; anti-actin (Abcam, Cambridge, UK), dilution 1:1000; anti-cTnT clone 1A11 (Research Diagnostics, Inc., Flanders, NJ, USA), dilution 1:3000; anti-Tm (Sigma-Aldrich), dilution 1:600; anti-cTnI clone 19C7 (Research Diagnostics), dilution 1:1000; antiMLC-1 (Santa Cruz Biotechnology, Dallas, TX, USA), dilution 1:7000; and anti-MLC-2 (Abcam), dilution 1:400. 
Peroxidase-conjugated secondary antibody was used as appropriate (Sigma-Aldrich), dilution 1:3000.

For myosin heavy chain (MHC) isoform analysis with Coomassie blue staining, rat ventricular tissues were homogenized under denaturing conditions. MHC isoforms ( $\alpha$ and $\beta$ ) were separated on a $4 \%$ polyacrylamide gel as described previously [27, 28]. $4 \mu \mathrm{g}$ of protein sample was loaded in each well. Electrophoresis was carried out at a constant $220 \mathrm{~V}$ for $3-3.5 \mathrm{~h}$ at around $15^{\circ} \mathrm{C}$. Gels were stained with Coomassie brilliant blue R-250 (Bio-Rad) for $2 \mathrm{~h}$, and then destained with $7 \%$ acetic acid by diffusion. Human failing heart ventricular sample served as $\alpha$-MHC and $\beta$-MHC isoform control. MHC isoforms were documented by GS-670 Imaging Densitometer (Bio-Rad).

For MHC Western immunoblot analysis, cardiac tissues were prepared as for the mechanical measurements, except that the isolated samples were dissolved in sample buffer instead of isolating solution. Male Sprague-Dawley soleus muscle was used as $\beta$-MHC control. MHC isoforms were separated on SDS-PAGE following earlier protocol [29] with modifications. Then proteins were transferred to nitrocellulose membrane and probed with primary (pan antiMHC, dilution 1:10000, from Sigma-Aldrich; and anti- $\beta$ MHC isoform: mouse IgM, MYH7 (A4.840) sc-53,089, dilution 1:1000, from Santa Cruz Biotechnology, Inc., Dallas, TX, USA) and secondary antibodies (peroxidase-conjugated secondary antibody, dilution 1:3000, from SigmaAldrich; and goat anti-mouse IgM, 115-035-075, dilution 1:20000, from Jackson ImmunoResearch Laboratories, Ltd., West Grove, PA, USA) as appropriate. Proteins were detected by ECL reaction and documented by MF-ChemiBIS 3.2 gel documentation system (DNR Bio-Imaging Systems, Ltd., Jerusalem, Israel). Signal intensities were evaluated by ImageJ $1.41 \mathrm{o}$ image processing program (National Institutes of Health, Bethesda, MD, USA). All biochemical analyses were performed on 4-6 samples/groups.

\section{Statistical analysis}

Data are expressed as mean \pm SEM. Statistical analysis was performed with GraphPad Prism 5.02 software (GraphPad Software, Inc., La Jolla, CA, USA). Differences were evaluated by one-way ANOVA followed by Bonferroni post hoc test. $P$ values of $<0.05$ were considered statistically significant.

\section{Results}

\section{$\mathrm{Ca}^{2+}$-paradox dramatically depresses $\mathrm{LV}$ contractile function in Langendorff hearts}

LVDP recorded in Control hearts $(127.4 \pm 6.1 \mathrm{mmHg})$ was permanently decreased during both $\mathrm{Ca}^{2+}$-depletion
$(9.8 \pm 1.3 \mathrm{mmHg}, \quad P<0.001) \quad$ and $\quad \mathrm{Ca}^{2+}$-paradox $(12.9 \pm 1.3 \mathrm{mmHg}, P<0.001$; Fig. 1 ; Table 1). Similarly, $+\mathrm{dP} / \mathrm{dt}$ and $-\mathrm{dP} / \mathrm{dt}$ in $\mathrm{Ca}^{2+}$-depletion $(62.6 \pm 6.9$ and $-87.9 \pm 12.6 \mathrm{mmHg} / \mathrm{sec}$, respectively, $P<0.001)$, as well as in $\mathrm{Ca}^{2+}$-paradox $(93.9 \pm 19.7$ and $-163.4 \pm 17.9 \mathrm{mmHg} /$ sec, respectively, $P<0.001)$ were significantly lower than in Controls $(7073.8 \pm 351.0$ and $-4075.3 \pm 206.2 \mathrm{mmHg} /$ sec, respectively; Fig. 1; Table 1). At the same time, LVEDP of Control hearts $(4.1 \pm 0.5 \mathrm{mmHg})$ was markedly increased due to both $\mathrm{Ca}^{2+}$-depletion $(32.2 \pm 3.3 \mathrm{mmHg}$, $P<0.001)$ and $\mathrm{Ca}^{2+}$-paradox $(72.4 \pm 5.0 \mathrm{mmHg}, P<0.001$; Fig. 1; Table 1).

\section{Myofibrillar $\mathrm{Ca}^{2+}$-stimulated ATPase activity is decreased, while $\mathrm{Mg}^{2+}$ ATPase activity is increased in $\mathrm{Ca}^{2+}$-paradox}

Compared to Control hearts $\left(12.08 \pm 0.57 \mu \mathrm{mol} \mathrm{P}_{\mathrm{i}} / \mathrm{mg}\right.$ protein/h), myofibrillar $\mathrm{Ca}^{2+}$-stimulated ATPase activity was decreased upon $\mathrm{Ca}^{2+}$-depletion $(8.13 \pm 0.19 \mu \mathrm{mol}$ $\mathrm{P}_{\mathrm{i}} / \mathrm{mg}$ protein $\left./ \mathrm{h}, P<0.001\right)$ as shown in Table 2 , and it remained low in $\mathrm{Ca}^{2+}$-paradox $\left(8.40 \pm 0.22 \mu \mathrm{mol} \mathrm{P}_{\mathrm{i}} / \mathrm{mg}\right.$ protein/h, $P<0.001$; Table 2). In contrast, Control $\mathrm{Mg}^{2+}$ ATPase activity $\left(3.20 \pm 0.25 \mu \mathrm{mol} \mathrm{P}_{\mathrm{i}} / \mathrm{mg}\right.$ protein $\left./ \mathrm{h}\right)$ was not altered by $\mathrm{Ca}^{2+}$-depletion $\left(3.27 \pm 0.10 \mu \mathrm{mol} \mathrm{P}_{\mathrm{i}} / \mathrm{mg}\right.$ protein $/ \mathrm{h}$ ), but it was increased through $\mathrm{Ca}^{2+}$-paradox $\left(7.21 \pm 0.36 \mu\right.$ mol $\mathrm{P}_{\mathrm{i}} / \mathrm{mg}$ protein $/ \mathrm{h}, P<0.001$; Table 2$)$.

\section{$\mathrm{Ca}^{2+}$-paradox impairs $\mathrm{Ca}^{2+}$-activated force generation of isolated cardiomyocytes}

Isolated and mounted cardiomyocytes from the Control, $\mathrm{Ca}^{2+}$-depletion, and $\mathrm{Ca}^{2+}$-paradox groups all had plain cross striation pattern (Fig. 2a). Corresponding original force recordings are shown in Fig. 2b. Either active tension (Fig. 3a) or $k_{\text {tr }}$ (Fig. 3c) versus pCa relationships of isolated cardiomyocytes presented obvious differences in $\mathrm{Ca}^{2+}$-related force production between the experimental groups. Maximal active tension of the $\mathrm{Ca}^{2+}$-depletion group was not significantly different $\left(21.04 \pm 2.32 \mathrm{kN} / \mathrm{m}^{2}\right)$ from the Control values $\left(25.07 \pm 3.51 \mathrm{kN} / \mathrm{m}^{2}\right)$, but in the $\mathrm{Ca}^{2+}$-paradox group it was significantly lower $(12.12 \pm 3.19$ $\mathrm{kN} / \mathrm{m}^{2}, P<0.05$; Fig. 3b). Relative to Control $k_{\mathrm{tr}}$ at saturating $\mathrm{Ca}^{2+}$ levels $\left(k_{\mathrm{tr}, \max }, 4.61 \pm 0.22\right)$, myocytes from the $\mathrm{Ca}^{2+}$-depleted hearts had lower $k_{\text {tr,max }}(3.85 \pm 0.21$, $P<0.05)$, such as those from $\mathrm{Ca}^{2+}$-paradoxical hearts (3.21 $\pm 0.23, P<0.001$; Fig. $3 \mathrm{~d}$ ).

Regarding $\mathrm{Ca}^{2+}$-sensitivity of the subjected cardiomyocytes (Fig. 4a), $\mathrm{pCa}_{50}$ value was $5.99 \pm 0.02$ in the $\mathrm{Ca}^{2+}$-depletion group, which was not significantly different from the $\mathrm{pCa}_{50}$ of the Controls $(5.94 \pm 0.02$; 


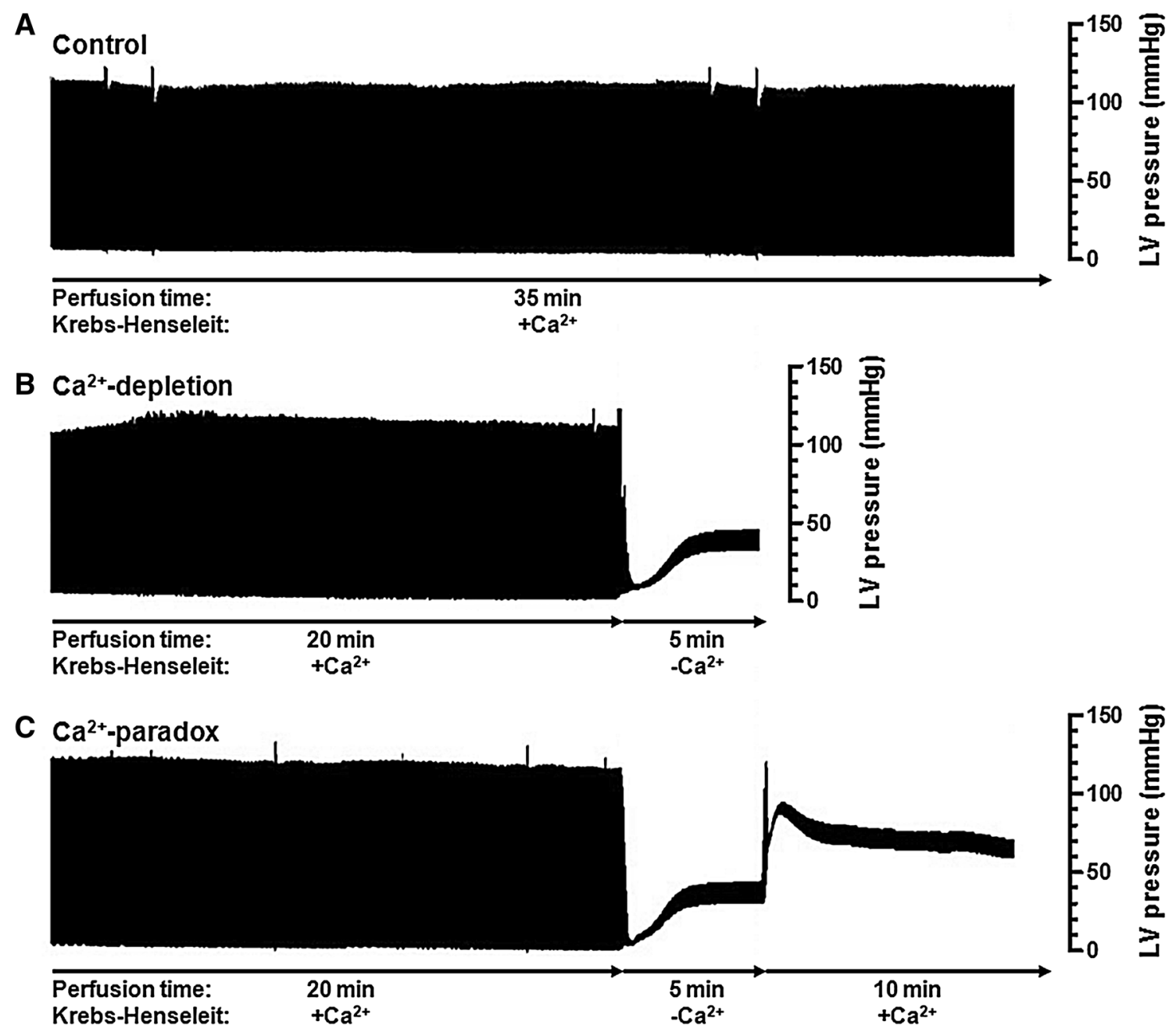

Fig. 1 Experimental model design and representative records of LV pressure measurements are demonstrated by Langendorff method. LV pressure is shown as a function of time in Control rat hearts $(\mathbf{a}), \mathrm{Ca}^{2+}$-depleted rat hearts $(\mathbf{b})$, and rat hearts exposed to $\mathrm{Ca}^{2+}$-paradox $(\mathbf{c})$

Table 1 LV contractile parameters in Control, $\mathrm{Ca}^{2+}$ depleted, and $\mathrm{Ca}^{2+}$-paradox rat hearts are given by Langendorff method

\begin{tabular}{lccr}
\hline Group & Control & $\begin{array}{l}\mathrm{Ca}^{2+} \text {-depletion } \\
(n=7-9)\end{array}$ & $\mathrm{Ca}^{2+}$-paradox \\
\hline Hemodynamic parameters & & & \\
LVDP, $\mathrm{mmHg}$ & $127.4 \pm 6.1$ & $9.8 \pm 1.3^{*}$ & $12.9 \pm 1.3^{*}$ \\
LVEDP, $\mathrm{mmHg}$ & $4.1 \pm 0.5$ & $32.2 \pm 3.3^{*}$ & $72.4 \pm 5.0^{*}, \#$ \\
$+\mathrm{dP} / \mathrm{dt}, \mathrm{mmHg} / \mathrm{sec}$ & $7073.8 \pm 351.0$ & $62.6 \pm 6.9^{*}$ & $93.9 \pm 19.7^{*}$ \\
$-\mathrm{dP} / \mathrm{dt}, \mathrm{mmHg} / \mathrm{sec}$ & $-4075.3 \pm 206.2$ & $-87.9 \pm 12.6^{*}$ & $-163.4 \pm 17.9^{*}$ \\
\hline
\end{tabular}

Data are given as mean \pm SEM

$L V D P$ LV developed pressure, $L V E D P$ LV end-diastolic pressure, $+d P / d t$ rate of pressure development in the $\mathrm{LV},-d P / d t$ rate of pressure decay in the $\mathrm{LV}$

${ }^{*} P<0.05$ versus Control; ${ }^{\#} P<0.05$ versus $\mathrm{Ca}^{2+}$-depletion
Fig. 4b). However, $\mathrm{pCa}_{50}$ was $5.90 \pm 0.03$ after $\mathrm{Ca}^{2+}$-repletion, indicating lower $\mathrm{Ca}^{2+}$-sensitivity than that in $\mathrm{Ca}^{2+}$-depletion $(P<0.05$; Fig. $4 \mathrm{~b})$. The $n_{\text {Hill }}$ values were not different between the Control, $\mathrm{Ca}^{2+}$-depletion, and $\mathrm{Ca}^{2+}$-paradox groups $(2.65 \pm 0.12,2.56 \pm 0.10$, and $2.59 \pm 0.14$, respectively; Fig. 4c). Figure 4d shows cardiomyocyte $\mathrm{Ca}^{2+}$-independent passive tension. Relative to Control $\left(2.13 \pm 0.29 \mathrm{kN} / \mathrm{m}^{2}\right)$, no change was 
Table 2 Basal $\mathrm{Mg}^{2+}$ dependent and $\mathrm{Ca}^{2+}$-stimulated myofibrillar ATPase activities are shown in Control, $\mathrm{Ca}^{2+}$ depleted, and $\mathrm{Ca}^{2+}$-paradox ventricles

\begin{tabular}{lll}
\hline Group & Control & $\begin{array}{l}\mathrm{Ca}^{2+} \text {-depletion } \\
(n=7-9)\end{array}$
\end{tabular}

\begin{tabular}{llll} 
ATPase activity & & & \\
Basal $\left(\mathrm{Mg}^{2+}\right), \mu \mathrm{mol} \mathrm{P}_{\mathrm{i}} / \mathrm{mg}$ protein/h & $3.20 \pm 0.25$ & $3.27 \pm 0.10$ & $7.21 \pm 0.36^{*}, \#$ \\
$\mathrm{Ca}^{2+}$-stimulated, $\mu \mathrm{mol} \mathrm{P}_{\mathrm{i}} / \mathrm{mg}$ protein/h & $12.08 \pm 0.57$ & $8.13 \pm 0.19^{*}$ & $8.40 \pm 0.22^{*}$ \\
\hline
\end{tabular}

Data are given as mean \pm SEM

${ }^{*} P<0.05$ versus Control; ${ }^{\#} P<0.05$ versus $\mathrm{Ca}^{2+}$-depletion
A
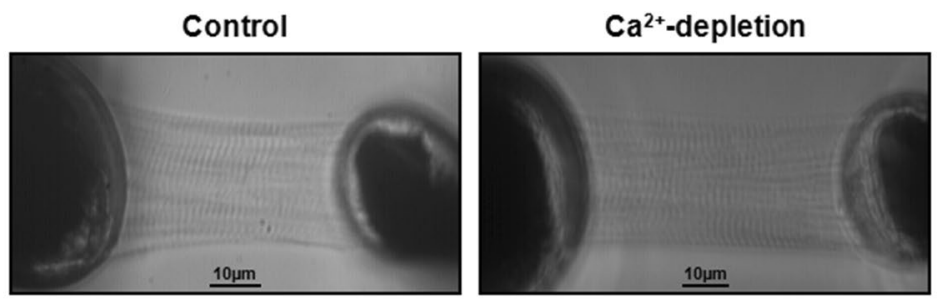

$\mathrm{Ca}^{2+}+$ paradox

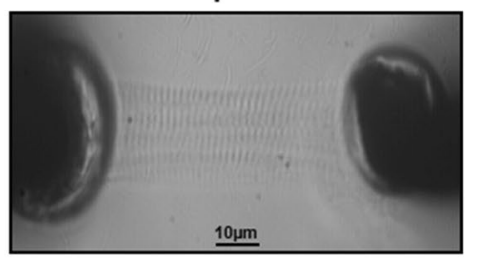

B

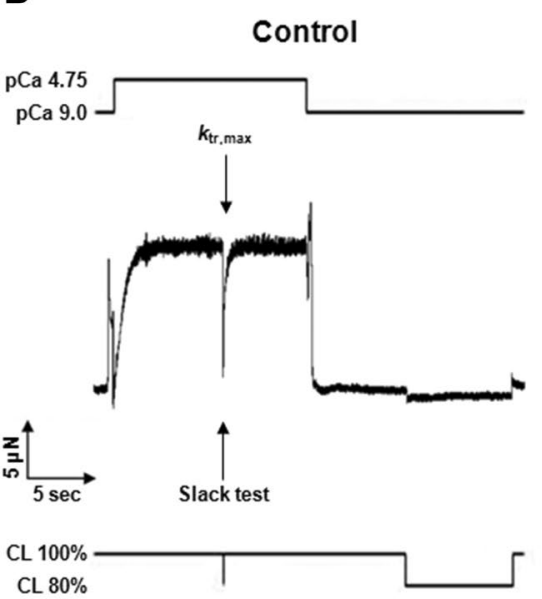

CL $80 \%$
$\mathrm{Ca}^{2+}$-depletion
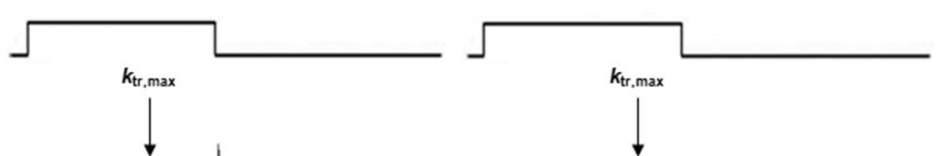

$\mathrm{Ca}^{2+}$-paradox

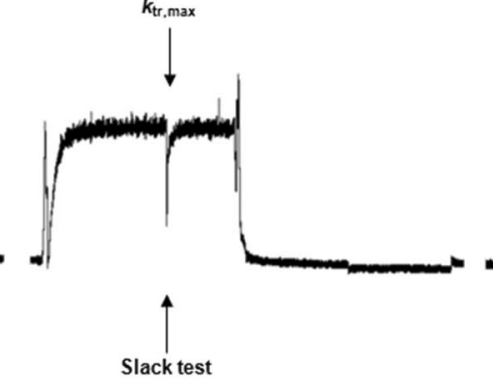

$\longrightarrow$
Fig. 2 Typical appearance and function of the contractile machinery are shown in Control, $\mathrm{Ca}^{2+}$-depletion, and $\mathrm{Ca}^{2+}$-paradox groups. a Each demembranated myocyte-sized preparation was mounted with silicone adhesive between a high-speed length controller (left) and a sensitive force transducer (right). Sarcomere length was set to $2.3 \mu \mathrm{m}$. Scale bars represent $10 \mu \mathrm{m}$. Note that apparently functional cardiomyocytes with plain cross striation pattern were selected and investigated. b Corresponding original force recordings demon-

observed in passive tension neither upon $\mathrm{Ca}^{2+}$-depletion $\left(2.11 \pm 0.54 \mathrm{kN} / \mathrm{m}^{2}\right)$ nor upon $\mathrm{Ca}^{2+}$-paradox $(2.25 \pm 0.35$ $\mathrm{kN} / \mathrm{m}^{2}$; Fig. $\left.4 \mathrm{~d}\right)$.

\section{$\mathrm{Ca}^{2+}$-paradox disturbs myofibrillar integrity, including $\alpha$-MHC and cTnT}

The protein composition of myocardial homogenates $(\leq 200 \mathrm{kDa})$ is shown with silver staining in Fig. 5a. In order to identify potential degrading proteins, we have strate experimental design of cellular force measurements. Maximal $\mathrm{Ca}^{2+}$-activated force generation was induced by transferring the preparation from relaxing solution with $-\log _{10}\left[\mathrm{Ca}^{2+}\right]$ (pCa) 9.0 to maximal activating solution with $\mathrm{pCa} 4.75$. Rapid slack test was performed at $\mathrm{pCa} 4.75$ for the determination of maximal rate constant of force regeneration $\left(k_{\mathrm{tr}, \max }\right)$. In relaxing solution again long slack test was then performed to measure $\mathrm{Ca}^{2+}$-independent force. $80 \%$ of initial cell length (CL) was considered as slack length tested the integrity of several myofibrillar proteins using Western immunoblot (Fig. 5b). Pan MHC Western immunoblot clearly identified additional bands with higher mobility than the parent molecules in $\mathrm{Ca}^{2+}$-depletion and $\mathrm{Ca}^{2+}$-paradox groups (Fig. 5b), suggesting MHC degradation. As explained by the species-dependent MHC isoform expression, $\beta$-MHC isoform was not recognized by Western immunoblot in our rat hearts (Fig. 6c). Therefore, the MHC we see in Fig. $5 b$ is $\alpha$-MHC, since only that isoform was expressed in our samples. The specific 
A

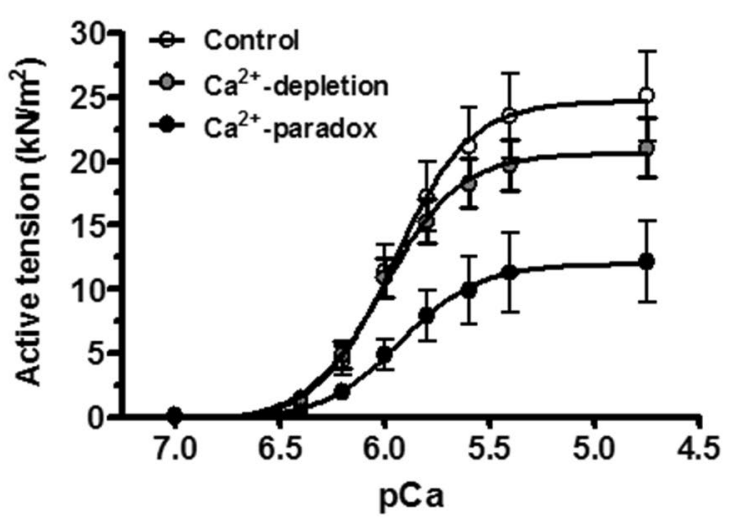

C

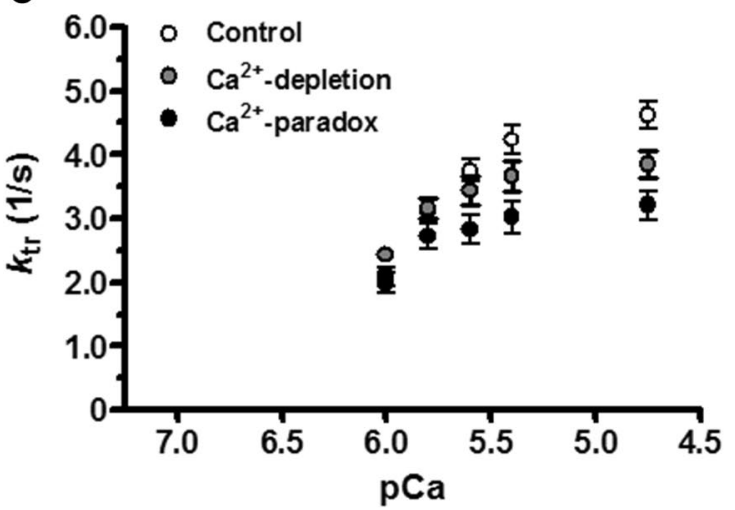

B
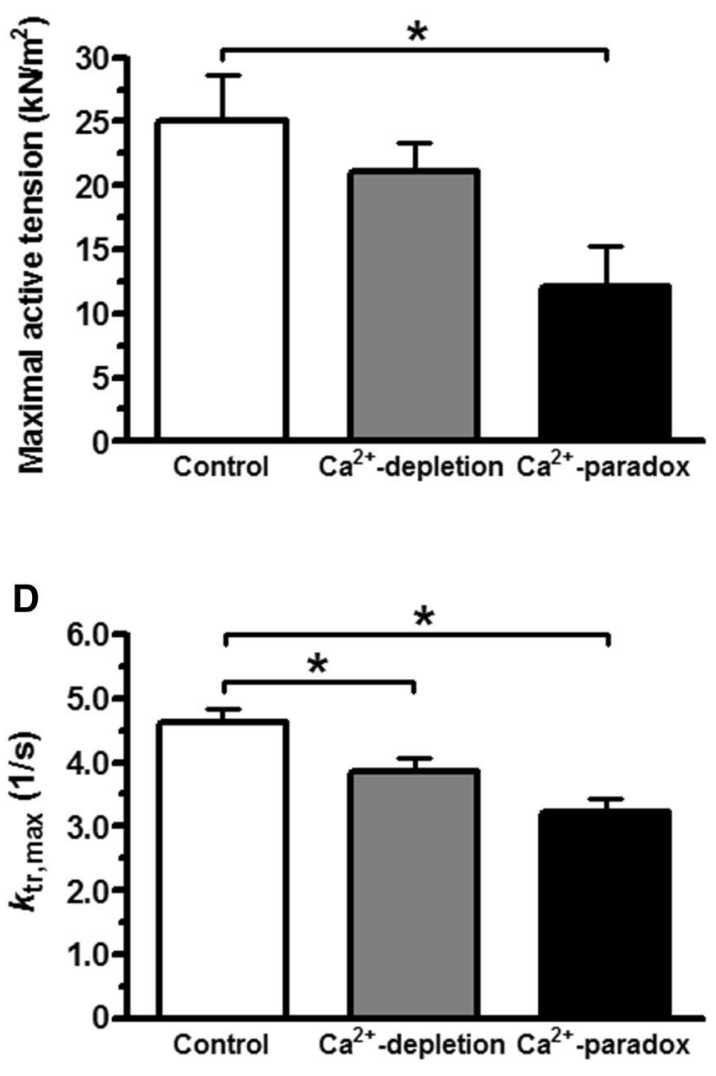

Fig. 3 Contractile performance of isolated cardiomyocytes is shown in Control, $\mathrm{Ca}^{2+}$-depleted and $\mathrm{Ca}^{2+}$-paradox groups. a Cardiomyocyte active tension is shown as a function of $\mathrm{pCa}$. Maximum points of active tension versus $\mathrm{pCa}$ relationships (at $\mathrm{pCa} 4.75$ ) are compared in b. b Maximal active tension values of the subjected cardiomyocytes

electrophoretic separation of MHC isoforms followed by Coomassie staining also confirms that the control samples express only the $\alpha$-MHC isoform (Fig. 6b) and this latter isoform showed up as a somewhat lower band in the $\mathrm{Ca}^{2+}$-depletion and $\mathrm{Ca}^{2+}$-paradox groups compared to the parent molecule of the Controls, indicating protein degradation (Fig. 6b). Moreover, cTnT also exhibited a progressive degradation during $\mathrm{Ca}^{2+}$-depletion then $\mathrm{Ca}^{2+}$-repletion as seen in Fig. 5b. In contrast, we found no changes in the protein amount and integrity of $\alpha$-actinin, desmin, actin, Tm, cTnI, MLC-1, and MLC-2 between the experimental groups (Fig. 5b). Titin did not show apparent degradation in $\mathrm{Ca}^{2+}$-depletion and $\mathrm{Ca}^{2+}$-paradox (Fig. 6a).

\section{Discussion}

For the first time, this study aimed to investigate the influence of $\mathrm{Ca}^{2+}$-paradox on cardiac function at cellular and myofibrillar level. Here we demonstrate that are compared on bar graphs. $\mathbf{c}$ Rate constant of force redevelopment $\left(k_{\mathrm{tr}}\right)$ of the contractile machinery is shown as a function of pCa. d Maximal $k_{\mathrm{tr}}$ values at saturating $\mathrm{Ca}^{2+}$ levels $\left(k_{\mathrm{tr} \text { max }}\right)$ are compared on bar graphs. Data are given as mean $\pm \mathrm{SEM} ; n=12-13$ cells/group; $* P<0.05$ versus Control

global contractile impairment of isolated hearts due to $\mathrm{Ca}^{2+}$-depletion then $\mathrm{Ca}^{2+}$-repletion is associated with altered myofibrillar ATPase activity and decreased $\mathrm{Ca}^{2+}$-dependent force production of single skinned cardiomyocytes. Furthermore, degradation of contractile proteins - such as $\alpha$-MHC and cTnT-occurs in hearts affected by $\mathrm{Ca}^{2+}$-paradox. These data suggest an insufficient actin-myosin interaction in intracellular $\mathrm{Ca}^{2+}$-overload, leading to contractile dysfunction presumably on the basis of myofibrillar damage.

In accordance with prior findings in $\mathrm{Ca}^{2+}$-paradox [5, 6], we observed global LV systolic dysfunction in both $\mathrm{Ca}^{2+}$-depletion and $\mathrm{Ca}^{2+}$-paradox indicated by a low LVDP associated with a uniform fall in $+\mathrm{dP} / \mathrm{dt}$ and $-\mathrm{dP} / \mathrm{dt}$. At the same time, as a result of the significant rise in LVEDP during $\mathrm{Ca}^{2+}$-depletion then $\mathrm{Ca}^{2+}$-replacement, these hearts manifested diastolic dysfunction as well. This observation is in line with earlier studies reporting increased resting tension in $\mathrm{Ca}^{2+}$-paradox [17]. Hypercontracture in $\mathrm{Ca}^{2+}$-paradoxical hearts $[4,8,10]$ is therefore likely to be 


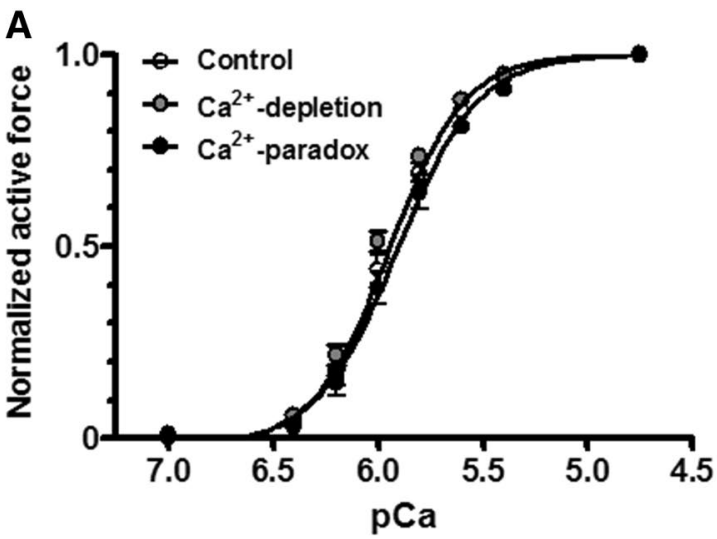

C

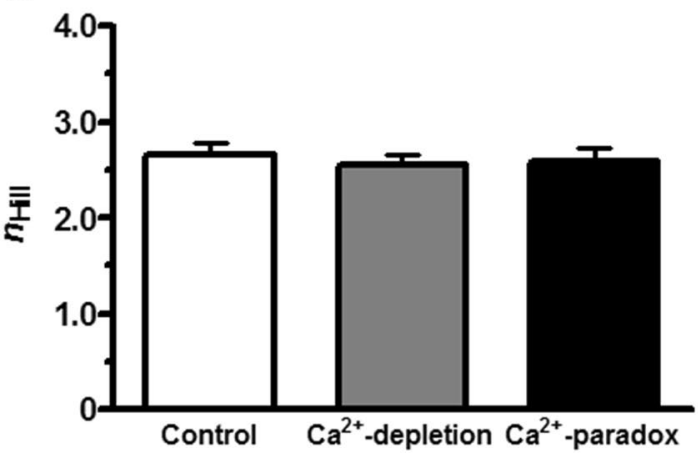

Fig. $4 \mathrm{Ca}^{2+}$-sensitivity, myofilament cooperation, and passive tension of cardiomyocytes are shown in Control, $\mathrm{Ca}^{2+}$-depleted, and $\mathrm{Ca}^{2+}$-paradox groups. a Normalized active force-pCa relationships provide the sigmoidal $\mathrm{Ca}^{2+}$-sensitivity curves of myocyte subjects. b $\mathrm{Ca}^{2+}$-sensitivity of the contractile apparatus $\left(\mathrm{pCa}_{50}\right)$ is shown on bar

functionally considered as a pathological condition of inadequate contraction and relaxation side by side.

Chemical energy required for myofilament contraction originates from ATP hydrolysis through myosin ATPase, while ATP binding again to myosin heads is needed for cardiac muscle relaxation cycle-to-cycle [30, 31]. Basal ATP hydrolysis by the $\mathrm{Mg}^{2+}$-dependent myosin ATPase activity triggers myosin off to a high-energy form binding $\mathrm{P}_{\mathrm{i}}$ and ADP. $\mathrm{Ca}^{2+}$-induced conformational changes in the troponin complex relieve myofilaments of inhibition making actin accessible for myosin heads, thereby facilitating cross-bridge formation. Dissociation of the $\mathrm{P}_{\mathrm{i}}$ from the bounded myofilaments is mediated by the $\mathrm{Ca}^{2+}$-stimulated myosin ATPase activity, initiating the power stroke. The subsequent release of ADP leads to rigor, in other words nucleotide-free myosin in low-energy form. The new coupling of ATP and myosin heads finally results in relaxation, detaching myosin from actin.

An increased diastolic tension and pressure therefore raise the lack of ATP as required for relaxation. Cytosolic ATP content, however, is not only preserved during hypercontracture that is provoked by intracellular $\mathrm{Ca}^{2+}$-overload,
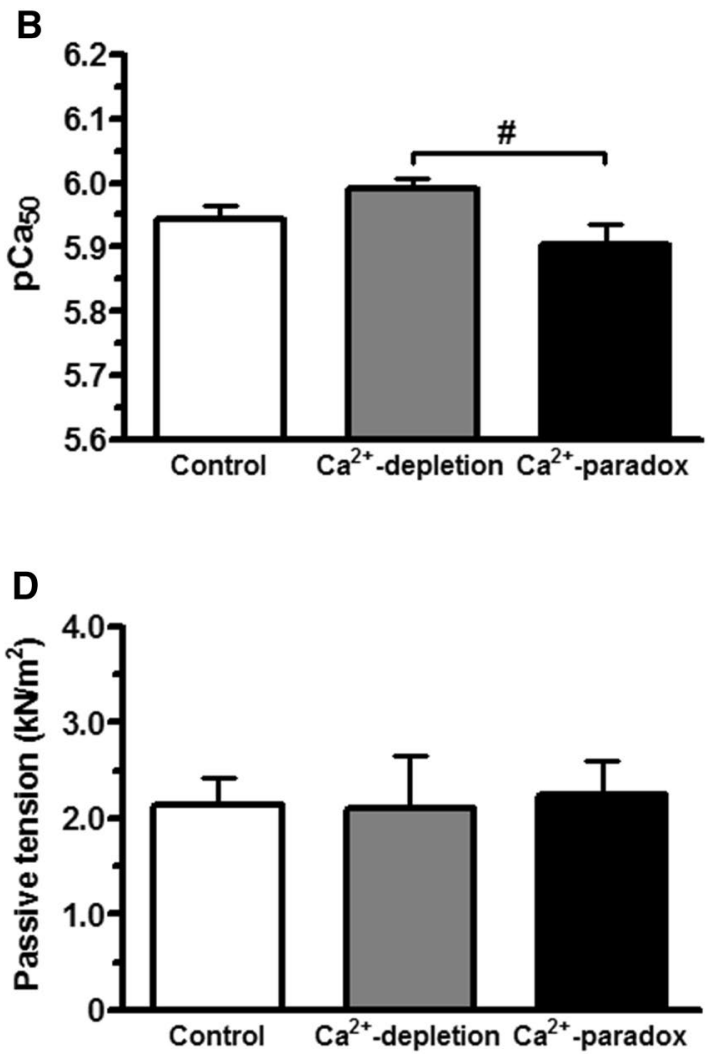

graphs. c Steepness of the normalized active force versus pCa curves represented by the Hill coefficient $\left(n_{\text {Hill }}\right)$ demonstrates myofilament cooperation in isolated cardiomyocytes. $\mathbf{d ~} \mathrm{Ca}^{2+}$-independent passive tension of the same cells is shown at $\mathrm{pCa}$ 9.0. Data are given as mean $\pm \mathrm{SEM} ; \mathrm{n}=12-13$ cells/group; ${ }^{\#} P<0.05$ versus $\mathrm{Ca}^{2+}$-depletion

but ATP has been demonstrated as a prerequisite in the development of $\mathrm{Ca}^{2+}$-paradox [32]. Nevertheless, studies of rigor tension on isolated skinned rat cardiomyocytes have revealed the possibility of ATP compartmentalization in ischemic contracture [33]. Accordingly, under certain pathological conditions $\left[\mathrm{Mg}^{2+}\right.$-ATP $]$ might differ in the myofibrils and in the cytosol. Based on this theory, one could speculate that depletion of ATP in the myofilament compartment might lead to impaired relaxation [34], thereby hypercontracture in $\mathrm{Ca}^{2+}$-paradoxical hearts, even if cytosolic ATP supply is preserved. Nonetheless, it has been already reported that contracture development is promoted by a rise in intracellular $\left[\mathrm{Ca}^{2+}\right]$ by activating ATPases, and consequently internal $\mathrm{Ca}^{2+}$-overload promotes ATP depletion and accelerates rigor tension development [3]. In myofibrils from isolated hearts suffered $\mathrm{Ca}^{2+}$-paradox, we documented an enhanced $\mathrm{Mg}^{2+}$-dependent ATPase, but a depressed $\mathrm{Ca}^{2+}$-stimulated ATPase activity. This observation implies that in $\mathrm{Ca}^{2+}$-paradox a higher rate of basal ATP hydrolysis on myosin heads is followed by a lower dissociation rate of ATP metabolites, contributing to stiffer actin-myosin interaction and/or local ATP 
A

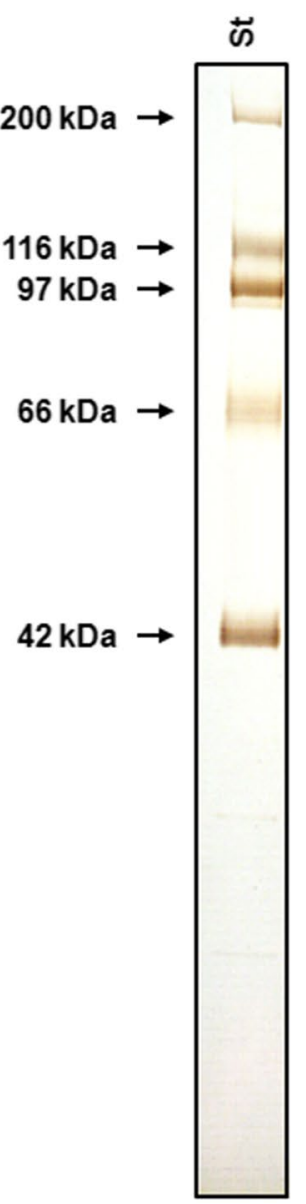

Fig. 5 Ventricular homogenates from Langendorff-perfused rat hearts were tested for protein degradation. a Representative protein compositions $(\leq 200 \mathrm{kDa})$ are shown on $6-18 \%$ gradient polyacrylamide gels by silver staining. One lane is shown of molecular weight standards (St), and Control, $\mathrm{Ca}^{2+}$-depletion, and $\mathrm{Ca}^{2+}$-paradox samples, respectively. Samples were run together, where black frames indicate gel discontinuity. b Myofilament proteins were identified

consumption under relaxed conditions. In the regulation of cardiac contraction, it is generally accepted that $\mathrm{Mg}^{2+}-\mathrm{ADP}$ binds strongly to myosin, promoting the isometric tension and decreasing tension kinetics [23]. Experiments on rat skinned fibers have demonstrated that $\mathrm{Mg}^{2+}$-ADP has a clear impact on rigor tension development as well as on myosin ATPase activity, suggesting that development of rigor cross-bridges might be related to an increase in myosin ATPase activity [34]. Indeed, in rat permeabilized cardiomyocytes rigor was associated with enhanced myosin ATPase activity; in addition, $\mathrm{Mg}^{2+}$-ADP was shown to stimulate myosin ATPase [35]. These results propose an inhibitory effect of $\mathrm{Mg}^{2+}$-ADP on dissociation steps
B
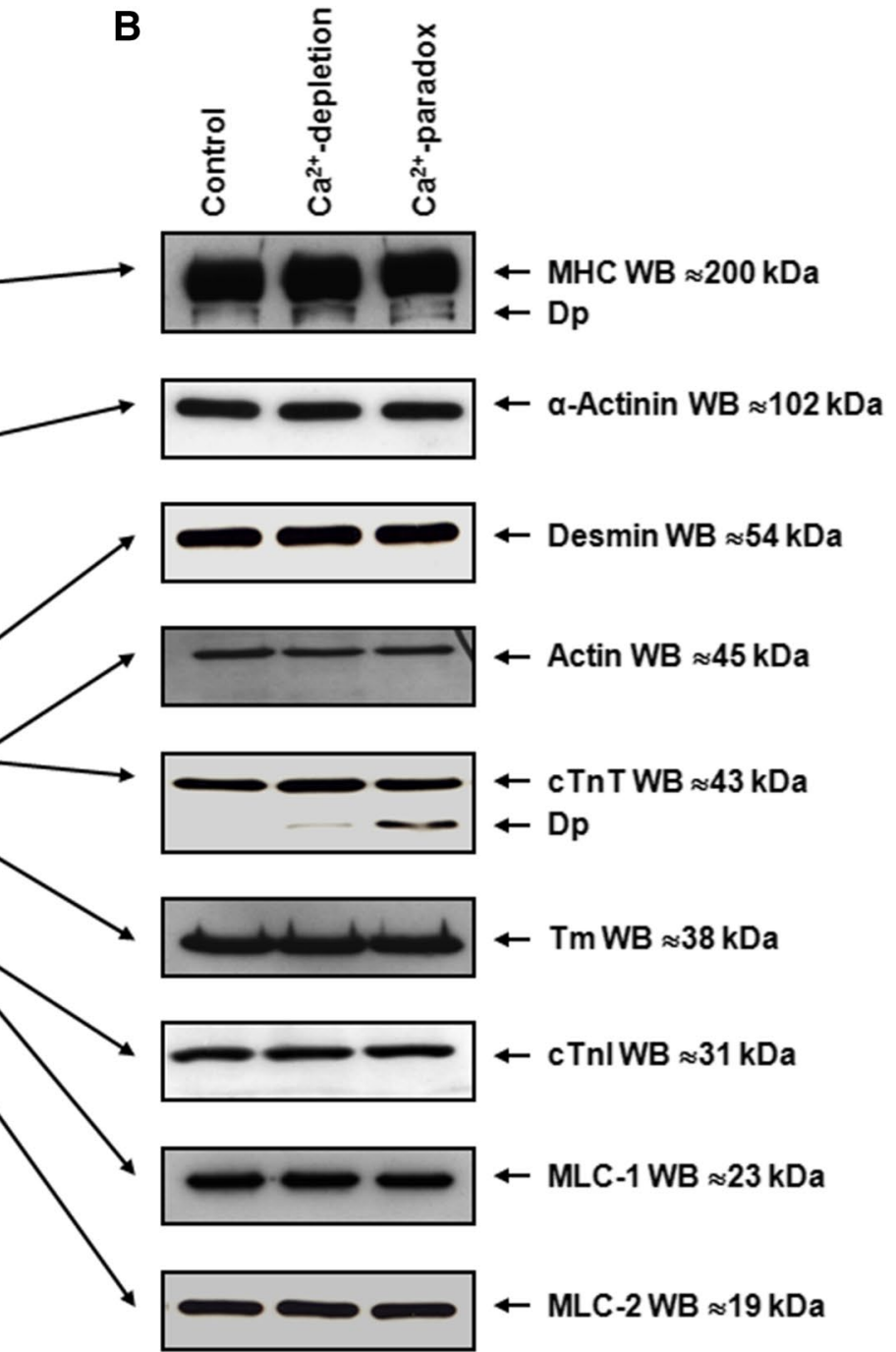

and tested for degradation by Western immunoblot (WB). Corresponding images (uncut between lanes) are representative examples. Protein bands around 200, 102, 54, 43, 38, 31, 23, and $19 \mathrm{kDa}$ were co-migrated with myosin heavy chain (MHC), $\alpha$-actinin, desmin, actin, cardiac troponin $\mathrm{T}(\mathrm{cTnT})$, tropomyosin $(\mathrm{Tm})$, cardiac troponin I (cTnI), myosin light chain-1 (MLC-1), and myosin light chain-2 (MLC-2), respectively

and/or on further $\mathrm{Mg}^{2+}$-ATP binding and cross-bridge detachment [34]. Since maximal speed of contraction is presumably controlled by the rate of cross-bridge detachment [30], the release of $\mathrm{Mg}^{2+}$-ADP becomes the main rate-limiting step in cross-bridge cycling, thereby in contracture development [34, 35]. Accordingly, it appears that the stimulated myosin ATPase in $\mathrm{Ca}^{2+}$-paradox is the $\mathrm{Mg}^{2+}$-dependent one, resulting in higher rate of ATP hydrolysis along with slower rate of $\mathrm{P}_{\mathrm{i}}$ and ADP release. This apparent discrepancy might lead to a proportionally increased number of myosin heads bounded to actin in each cross-bridge cycle. The stiff actin-myosin interaction and/ or elevated basal ATP consumption then might result in 

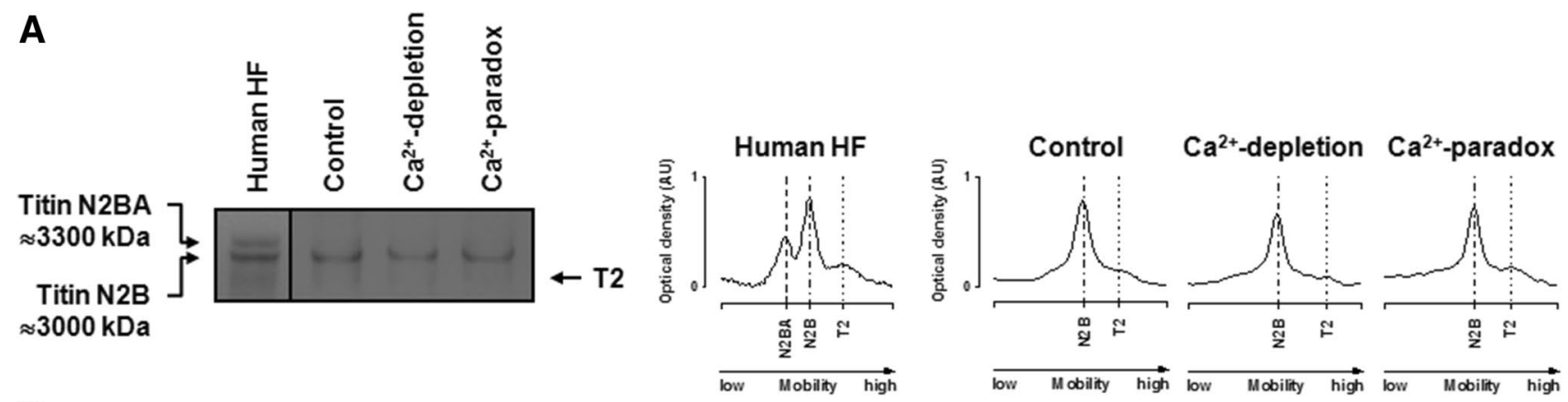

B
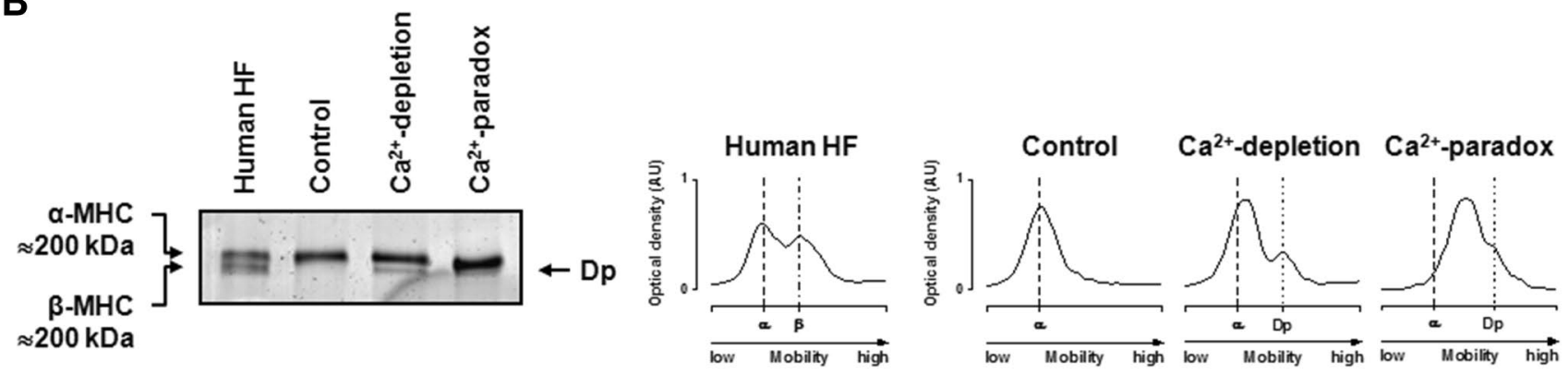

C

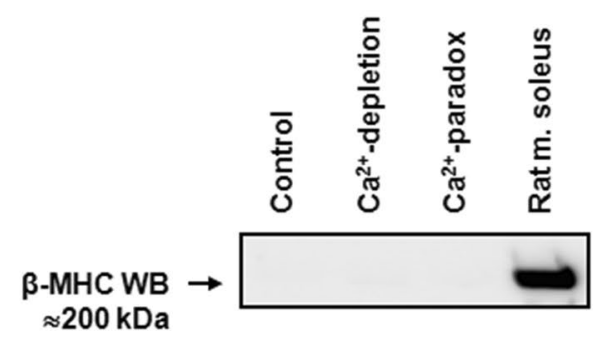

Fig. 6 Titin and myosin heavy chain (MHC) isoform compositions are shown in Control, $\mathrm{Ca}^{2+}$-depletion, and $\mathrm{Ca}^{2+}$-paradox ventricular samples. a Representative image shows titin isoform separation on agarose-strengthened polyacrylamide gels. Protein bands were visualized with Coomassie. Black line indicates discontinuity between lanes. Human heart failure (HF) ventricular sample served as titin isoform control showing protein bands with lower mobility around $3300 \mathrm{kDa}(\mathrm{N} 2 \mathrm{BA})$ and with higher mobility around $3000 \mathrm{kDa}(\mathrm{N} 2 \mathrm{~B})$. $\mathrm{T} 2$ band is considered as a barely detectable large titin degradation product. Corresponding optical densities - in arbitrary units (AU) show only N2B titin isoform with similar mobility and no apparent degradation in Control, $\mathrm{Ca}^{2+}$-depletion, and $\mathrm{Ca}^{2+}$-paradox groups. Three titin separations in duplicates in all experimental groups gave similar results. b MHC isoforms were separated on polyacrylamide

high resting tension. This theory might explain increased LVEDP seen in $\mathrm{Ca}^{2+}$-paradox, despite the fact that diastolic intracellular $\left[\mathrm{Ca}^{2+}\right]$ is relatively low during $\mathrm{Ca}^{2+}$-paradox [36]. On the other hand, we found that in $\mathrm{Ca}^{2+}$-depleted and $\mathrm{Ca}^{2+}$-paradoxical hearts, global impairment of systolic function was associated with depressed myofibrillar $\mathrm{Ca}^{2+}$-stimulated ATPase activity. It has been known for a long time that myosin ATPase determines the velocity of muscle contraction [37], and thus indices of $\mathrm{Ca}^{2+}$-activated contraction rate (e.g., dP/dt) are tightly correlated with gels and stained with Coomassie. Human HF ventricular sample served as $\alpha$-MHC and $\beta$-MHC isoform control where both isoforms could be detected. Only one MHC isoform could be identified in Control samples at the level of the $\alpha-\mathrm{MHC}$ isoform. Appearance of the lower band(s) in the $\mathrm{Ca}^{2+}$-depletion and $\mathrm{Ca}^{2+}$-paradox groups supports protein degradation. Corresponding optical densities-in AUconfirm higher mobility of the parent MHC molecule ( $\alpha$ isoform) and the co-appearance of a degradation product $(\mathrm{Dp})$ in $\mathrm{Ca}^{2+}$-depletion and $\mathrm{Ca}^{2+}$-paradox groups. Five different MHC separations in all experimental groups gave similar results. $\mathbf{c}$ The apparent lack of protein bands around $200 \mathrm{kDa}$ co-migrating with $\beta$-MHC isoform in Control, $\mathrm{Ca}^{2+}$-depletion, and $\mathrm{Ca}^{2+}$-paradox groups is demonstrated by Western immunoblot (WB). Rat musculus (m.) soleus skeletal muscle was used as antibody control

$\mathrm{Ca}^{2+}$-stimulated ATPase activity of myofibrils as elementary for initiating power stroke [30]. Consequently, low $\mathrm{Ca}^{2+}$-stimulated ATPase activity is associated with reduced $\mathrm{Ca}^{2+}$-dependent contraction, resulting in systolic dysfunction, like in $\mathrm{Ca}^{2+}$-paradox hearts.

Beyond that, for the first time we made an attempt to test cellular mechanical function in $\mathrm{Ca}^{2+}$-paradox, and described a significant decrease in maximal active tension and $k_{\text {tr,max }}$ of still surviving isolated cardiomyocytes after Langendorff-perfusion. These results from single-cell 
preparations are consistent with our LV contractility findings, since we consider reduced active tension as the cellular basis of depressed LVDP. Similar drop in $+\mathrm{dP} / \mathrm{dt}$ and $-\mathrm{dP} / \mathrm{dt}$ is the global reflection of reduced $k_{\mathrm{tr} \text { max }}$ by reason of depressed $\mathrm{Ca}^{2+}{ }_{\text {-stimulated ATPase activity. In contrast to }}$ $\mathrm{Ca}^{2+}$-dependent parameters, passive tension of isolated cardiomyocytes was not affected at all during $\mathrm{Ca}^{2+}$-depletion then $\mathrm{Ca}^{2+}$-replacement. Thus, passive myofilament components of diastole appear unlikely to be primarily responsible for myocardial stiffening in $\mathrm{Ca}^{2+}$-paradox.

Here we detected a gradual damage of essential contractile proteins, such as $\alpha-\mathrm{MHC}$ and cTnT en route to $\mathrm{Ca}^{2+}$-paradox. Based on previous observations, limited degradation of myofibrils might occur after $\mathrm{Ca}^{2+}$-paradox, suggesting cTnT release through membrane destruction [38]. Likewise homogenates from guinea pig hearts exposed to $\mathrm{Ca}^{2+}$-overload exhibited degradation of cTnT. A potential cross-linking between troponin subunits or their fragments and other cardiac proteins was therefore suggested in cell death after $\mathrm{Ca}^{2+}{ }_{-}$paradox [39]. These results are clearly in accordance with our findings based on Western blot assays suggesting progressive cTnT degradation upon $\mathrm{Ca}^{2+}$-depletion and $\mathrm{Ca}^{2+}$-repletion, although we did not observe cross-linked cTnT forms.

In summary, isolated rat hearts suffered $\mathrm{Ca}^{2+}$-paradox demonstrate impaired global and cellular contractility that is accompanied by decreased $\mathrm{Ca}^{2+}$-stimulated ATPase activity potentially as a result of myofilament protein degradation. According to data provided in this study, we conclude that significant deterioration in cardiac relaxation seen in $\mathrm{Ca}^{2+}$-paradoxical hearts is probably due to a failure in cross-bridge cycling because of an altered myofibrillar ATPase activity, and is apparently not directly related to titin. On the other hand, it is likely that one of the molecular bases of dramatic decrease in systolic function in $\mathrm{Ca}^{2+}$-paradox might be $\alpha$-MHC and cTnT cleavage, resulting in a collective reduction of interdependent parameters of $\mathrm{Ca}^{2+}$-dependent force generation at the level of cardiomyocytes, myofibrils, and isolated heart.

\begin{abstract}
Acknowledgements This work was supported by a grant from the Canadian Institutes of Health Research (CIHR), the Hungarian Scientific Research Fund (K116940 to AT and K109083 to ZP), the New National Excellence Program of the Ministry of Human Capacities (Hungary, to ÁK), the GINOP-2.3.2-15-2016-00043 (IRONHEART) by the Hungarian Ministry of National Economy and co-financed by the European Regional Development Fund. JB was a fellow of the TACTICS program, in association with CIHR and Heart and Stroke Foundation of Canada.
\end{abstract}

\section{Compliance with ethical standards}

Conflict of interest The authors declare that they have no conflict of interest.
Open Access This article is distributed under the terms of the Creative Commons Attribution 4.0 International License (http:// creativecommons.org/licenses/by/4.0/), which permits unrestricted use, distribution, and reproduction in any medium, provided you give appropriate credit to the original author(s) and the source, provide a link to the Creative Commons license, and indicate if changes were made.

\section{References}

1. Zimmerman AN, Hülsmann WC (1966) Paradoxical influence of calcium ions on the permeability of the cell membranes of the isolated rat heart. Nature 211(5049):646-647

2. Zimmerman AN, Daems W, Hülsmann WC, Snijder J, Wisse E, Durrer D (1967) Morphological changes of heart muscle caused by successive perfusion with calcium-free and calcium-containing solutions (calcium paradox). Cardiovasc Res 1(3):201-209

3. Steenbergen C, Murphy E, Watts JA, London RE (1990) Correlation between cytosolic free calcium, contracture, ATP, and irreversible ischemic injury in perfused rat heart. Circ Res 66(1):135-146

4. Piper HM (2000) The calcium paradox revisited: an artefact of great heuristic value. Cardiovasc Res 45(1):123-127

5. Zhang M, Xu YJ, Saini HK, Turan B, Liu PP, Dhalla NS (2005) TNF-alpha as a potential mediator of cardiac dysfunction due to intracellular $\mathrm{Ca}^{2+}$-overload. Biochem Biophys Res Commun 327(1):57-63

6. Xu YJ, Saini HK, Zhang M, Elimban V, Dhalla NS (2006) MAPK activation and apoptotic alterations in hearts subjected to calcium paradox are attenuated by taurine. Cardiovasc Res 72(1):163-174

7. Yates JC, Dhalla NS (1975) Structural and functional changes associated with failure and recovery of hearts after perfusion with $\mathrm{Ca}^{2+}$-free medium. J Mol Cell Cardiol 7(2):91-103

8. Ganote CE, Nayler WG (1985) Contracture and the calcium paradox. J Mol Cell Cardiol 17(8):733-745

9. Mani H, Tanaka H, Adachi T, Ikegawa M, Dai P, Fujita N, Takamatsu $\mathrm{T}$ (2015) How does the $\mathrm{Ca}^{2+}$-paradox injury induce contracture in the heart? A combined study of the intracellular $\mathrm{Ca}^{2+}$ dynamics and cell structures in perfused rat hearts. Acta Histochem Cytochem 48(1):1-8

10. Daly MJ, Elz JS, Nayler WG (1987) Contracture and the calcium paradox in the rat heart. Circ Res 61(4):560-569

11. Kawabata K, Osada M, Netticadan T, Dhalla NS (1998) Beneficial effect of ischemic preconditioning on $\mathrm{Ca}^{2+}$ paradox in the rat heart. Life Sci 63(8):685-692

12. Piper HM, Spahr R, Hütter JF, Spieckermann PG (1985) The calcium and the oxygen paradox: non-existent on the cellular level. Basic Res Cardiol 80(Suppl 2):159-163

13. Frank JS, Brady AJ, Farnsworth S, Mottino G (1986) Ultrastructure and function of isolated myocytes after calcium depletion and repletion. Am J Physiol 250(2 Pt 2):H265-H275

14. Kojima A, Kitagawa H, Omatsu-Kanbe M, Matsuura H, Nosaka S (2010) $\mathrm{Ca}^{+}$paradox injury mediated through TRPC channels in mouse ventricular myocytes. $\mathrm{Br} \mathrm{J}$ Pharmacol 161(8):1734-1750

15. Post JA, Nievelstein PF, Leunissen-Bijvelt J, Verkleij AJ, Ruigrok TJ (1985) Sarcolemmal disruption during the calcium paradox. J Mol Cell Cardiol 17(3):265-273

16. Preuner J (1985) Functional alterations of the sarcolemma in $\mathrm{Ca}^{2+}$-free perfused hearts. Basic Res Cardiol 80(Suppl 2):19-23 
17. Alto LE, Dhalla NS (1981) Role of changes in microsomal calcium uptake in the effects of reperfusion of $\mathrm{Ca}^{2+}$-deprived rat hearts. Circ Res 48(1):17-24

18. Samarel AM, Ferguson AG, Vander Heide RS, Davison R, Ganote CE (1986) Release of unassembled rat cardiac myosin light chain 1 following the calcium paradox. Circ Res 58(1):166-171

19. Zhang JY, Tong W, Wu F, Bi SH, Xu M, Jin ZX, Yang Y, Jiang XF, Zhou JJ (2012) Different roles for contracture and calpain in calcium paradox-induced heart injury. PLoS ONE 7(12):e52270

20. Solaro RJ, Pang DC, Briggs FN (1971) The purification of cardiac myofibrils with Triton X-100. Biochim Biophys Acta 245(1):259-262

21. Pierce GN, Dhalla NS (1985) Mechanisms of the defect in cardiac myofibrillar function during diabetes. Am J Pysiol 248(2 Pt 1):E170-E175

22. Taussky HH, Shorr E (1953) A microcolorimetric method for the determination of inorganic phosphorus. J Biol Chem 202(2):675-685

23. Papp Z, Szabó A, Barends JP, Stienen GJ (2002) The mechanism of the force enhancement by MgADP under simulated ischaemic conditions in rat cardiac myocytes. J Phyisol 543(Pt 1):177-189

24. Giulian GG, Moss RL, Greaser M (1983) Improved methodology for analysis and quantitation of proteins on one-dimensional silver-stained slab gels. Anal Biochem 129(2):277-287

25. Kovács Á, Fülöp GÁ, Kovács A, Csípó T, Bódi B, Priksz D, Juhász B, Beke L, Hendrik Z, Méhes G, Granzier HL, Édes I, Fagyas M, Papp Z, Barta J, Tóth A (2016) Renin overexpression leads to increased titin-based stiffness contributing to diastolic dysfunction in hypertensive mRen2 rats. Am J Physiol Heart Circ Physiol 310(11):H1671-H1682

26. Barta J, Tóth A, Edes I, Vaszily M, Papp JG, Varró A, Papp Z (2005) Calpain-1-sensitive myofibrillar proteins of the human myocardium. Mol Cell Biochem 278(1-2):1-8

27. Cummins P, Lambert SJ (1986) Myosin transitions in the bovine and human heart. A developmental and anatomical study of heavy and light chain subunits in the atrium and ventricle. Circ Res 58(6):846-858

28. Caforio AL, Grazzini M, Mann JM, Keeling PJ, Bottazzo GF, McKenna WJ, Schiaffino S (1992) Identification of alpha- and beta-cardiac myosin heavy chain isoforms as major autoantigens in dilated cardiomyopathy. Circulation 85(5):1734-1742

29. Talmadge RJ, Roy RR (1993) Electrophoretic separation of rat skeletal muscle myosin heavy-chain isoforms. J Appl Physiol 75(5):2337-2340

30. Brenner B, Eisenberg E (1986) Rate of force generation in muscle: correlation with actomyosin ATPase activity in solution. Proc Natl Acad Sci USA 83(10):3542-3546

31. Smith GA, Vandenberg JI, Freestone NS, Dixon HB (2001) The effect of $\mathrm{Mg} 2+$ on cardiac muscle function: is CaATP the substrate for priming myofibril cross-bridge formation and $\mathrm{Ca}^{2+}$ reuptake by the sarcoplasmic reticulum? Biochem J 354(Pt 3):539-551

32. Ruigrok TJ, Boink AB, Spies F, Blok FJ, Maas AH, Zimmerman AN (1978) Energy dependence of the calcium paradox. J Mol Cell Cardiol 10(11):991-1002

33. Veksler VI, Lechene P, Matrougui K, Ventura-Clapier R (1997) Rigor tension in single skinned rat cardiac cell: role of myofibrillar creatine kinase. Cardiovasc Res 36(3):354-362

34. Ventura-Clapier R, Veksler V (1994) Myocardial ischemic contracture. Metabolites affect rigor tension development and stiffness. Circ Res 74(5):920-929

35. Stapleton MT, Allshire AP (1998) Modulation of rigor and myosin ATPase activity in rat cardiomyocytes. J Mol Cell Cardiol 30(7):1349-1358

36. Jansen MA, Badlou BA, van Echteld CJ, Ruigrok TJ (2000) Cytosolic $\mathrm{Ca}^{2+}$ concentration during $\mathrm{Ca}^{2+}$ depletion of isolated rat hearts. Mol Cell Biochem 203(1-2):169-175

37. Bárány M (1967) ATPase activity of myosin correlated with speed of muscle shortening. J Gen Physiol 50(6):197-218

38. Remppis A, Scheffold T, Greten J, Haass M, Greten T, Kübler W, Katus HA (1995) Intracellular compartmentation of troponin T: release kinetics after global ischemia and calcium paradox in the isolated perfused rat heart. J Mol Cell Cardiol 27(2):793-803

39. Gorza L, Menabò R, Vitadello M, Bergamini CM, Di Lisa F (1996) Cardiomyocyte troponin T immunoreactivity is modified by cross-linking resulting from intracellular calcium overload. Circulation 93(10): 1896-1904 